\title{
COMBINED LATTICE AND VIERENDEEL GIRDER IN LONG-SPAN STEEL FRAME
}

\author{
Ivan Lukačević \\ University of Zagreb, Faculty of Civil Engineering, Ph.D. \\ Corresponding author: ica@grad.hr \\ Marko Ptiček \\ University of Zagreb, Faculty of Civil Engineering, Student \\ Darko Dujmović \\ University of Zagreb, Faculty of Civil Engineering, Full Professor
}

\begin{abstract}
A lattice girder frame was compared with a combined lattice and Vierendeel girder frame on a singlestory building with a frame span of $62.0 \mathrm{~m}$, column height of $15.0 \mathrm{~m}$, and ridge height of $17.3 \mathrm{~m}$. The lattice girder frame has the advantage of being a cheaper solution when considering steel usage. In contrast, the combined girder frame is a less complex production that has the advantage of cheaper labor costs in relation to the higher material consumption costs. The T-joint in Vierendeel girders, designed in accordance with EN 1993-1-8, was analyzed because of its key importance when designing the overall frame. Guidelines for the preliminary selection of the chord and post member cross sections in the Vierendeel girders based on their geometrical compatibility are given in this paper. This paper also describes a method for selecting the optimal static system for combined girder frames to achieve a more uniform bending moment distribution along the frame girder by adding additional posts.
\end{abstract}

Keywords: lattice girder; Vierendeel girder; long-span steel frame; T-joints

\section{KOMBINIRANI SUSTAV REŠETKE I VIERENDEEL NOSAČA KAO PREČKA ČELIČNOG OKVIRA VELIKOG RASPONA}

Sažetak: Na primjeru hale s okvirnim nosačem raspona $62,0 \mathrm{~m}$, visine stupa $15,0 \mathrm{~m}$ i visine u sljemenu $17,3 \mathrm{~m}$, provedena je usporedba okvira $s$ rešetkastom prečkom i okvira $s$ kombiniranom prečkom od rešetkastog $i$ Vierendeel nosača. Usporedbom utroška čelika, okvir s rešetkastom prečkom ističe se kao jeftinije rješenje. S druge strane, prednost okvira s kombiniranom prečkom je jednostavnija izvedba, koja se ističe u slučaju potrebe jeftinije cijene rada u odnosu na cijenu materijala. Analizirana je problematika dimenzioniranja T-priključaka prema EN 1993-1-8 kod Vierendeel nosača, jer su se pokazali kao jedan od najvažnijih čimbenika prilikom dimenzioniranja cijelog okvira. U radu su dane smjernice za preliminarni odabir poprečnih presjeka elemenata Vierendeel nosača, ovisno o njihovoj geometrijskoj kompatibilnosti. Za okvire s kombiniranom prečkom prikazan je odabir optimalnog statičkog sustava dodavanjem dodatnih ispuna u Vierendeel nosaču radi postizanja ravnomjernije raspodjele momenata savijanja u prečki okvira.

Ključne riječi: rešetkasti nosač; Vierendeel nosač; čelični okvir velikog raspona; T-priključci 


\section{INTRODUCTION}

This paper compares a combined lattice and Vierendeel girder (combined girder) in long-span steel frame (Figure 1a) with a lattice girder frame (Figure 1b). First, the advantages of the combined lattice and Vierendeel girder frame are given. Post-to-chord member joints in Vierendeel girders have a significant influence when designing the overall frame because they transfer significant bending moments. For that reason, a detailed description of these joints is given along with guidelines for the preliminary selection of the chord and post cross sections.

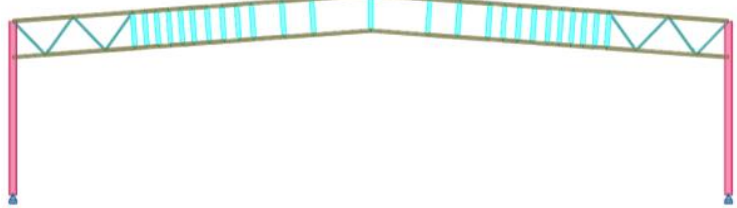

a) Combined lattice and Vierendeel girder frame

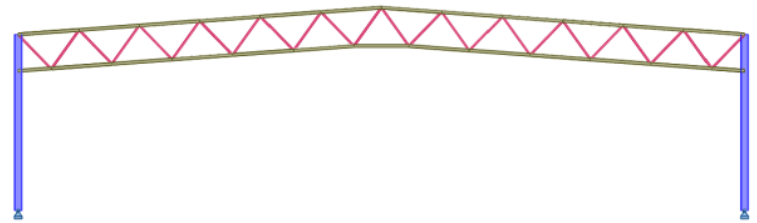

b) Lattice girder frame

Figure 1 Analyzed frame types

The lattice and combined girder frames were compared on a single-story building with layout dimensions of $100.0 \mathrm{~m} \times 62.0 \mathrm{~m}$, a column height of $15.0 \mathrm{~m}$, and a ridge height of $17.3 \mathrm{~m}$. For the same single-story building dimensions, two cases with frame spacings of 12.5 and $5.0 \mathrm{~m}$ were analyzed. In addition, the effect of adjusting and condensing the Vierendeel posts was investigated to determine how a more uniform bending moment distribution along the frame girder can be achieved. Two combined girder frames were selected and compared with a conventional lattice girder frame. These three frame systems and two frame spacings constitute a total of six frames. The frames were compared after being dimensioned in Autodesk Robot Structural Analysis Professional 2015 [1].

\section{ADVANTAGES OF COMBINED LATTICE AND VIERENDEEL GIRDER}

Vierendeel girders are named after Arthur Vierendeel (1852-1940), a Belgian engineer and university professor from Leuven. His idea of a new truss system was first realized and presented at the 1897 World Fair in Brussels, for which he built a 31.5-m span bridge at his own expense to prove the correlation between his calculations and measured results [2].

The concept underlying his truss system significantly differs from that of conventional systems, in which chords together with braces achieve the static continuity of the axial forces, thereby forming triangular units. In contrast, for Vierendeel girders, the units are rectangular, and the influence of the bending moments is a significant factor to consider when designing T-joints according to EN 1993-1-8 [3].

When Vierendeel girders are used as part of truss girders in frame systems, first, it is crucial to comprehend the function of a truss girder in a simple beam application. A truss girder is a system of elements, chords, and bracings set to withstand internal forces and bending moments. A chord experiences a bending moment when two axial forces with moment arm lengths equal to the truss height are applied to the chord. Therefore, the maximum axial force is in the middle of the girder span. Furthermore, the brace elements experience shear forces, the maximum values of which are located on the girder edges.

The comparison of the lattice and combined girder frames presented in this paper confirms that the lattice girder frame is superior in terms of weight and steel usage. However, the advantage of using a Vierendeel girder in steel frame systems is evident when a reduction in labor costs is desired, i.e., when, hypothetically, the labor is more expensive than the material (steel) itself. Specifically, the cost of producing Vierendeel girders is lower than that of lattice girders because of the relative simplicity of perpendicular element cutting, the ability to automate production using elements of equal length, easier access to joints during welding, and the simpler design allowed by the lower precision requirements in the production process $[4,5]$.

Considering these factors, Vallourec \& Mannesmann Tubes in cooperation with Dittmann und Pollmann patented a girder system called the PREON girder that combines the classic lattice and Vierendeel girders [5]. The concept underlying the PREON girder is based on a combination of the two above-mentioned static systems that features the main advantages of each. A lattice girder is used at the edges of the girder, where the highest shear 
force is applied, and it withstands the shear force with the system of axial forces, whereas a Vierendeel girder is used in the middle of the span, where the shear forces are lowest, as shown in Figure 2. The construction of the girder is modular with edge lattice segments of a constant length and a Vierendeel segment of variable length depending on the required girder span. This allows the use of a simpler design and rapid automated production.

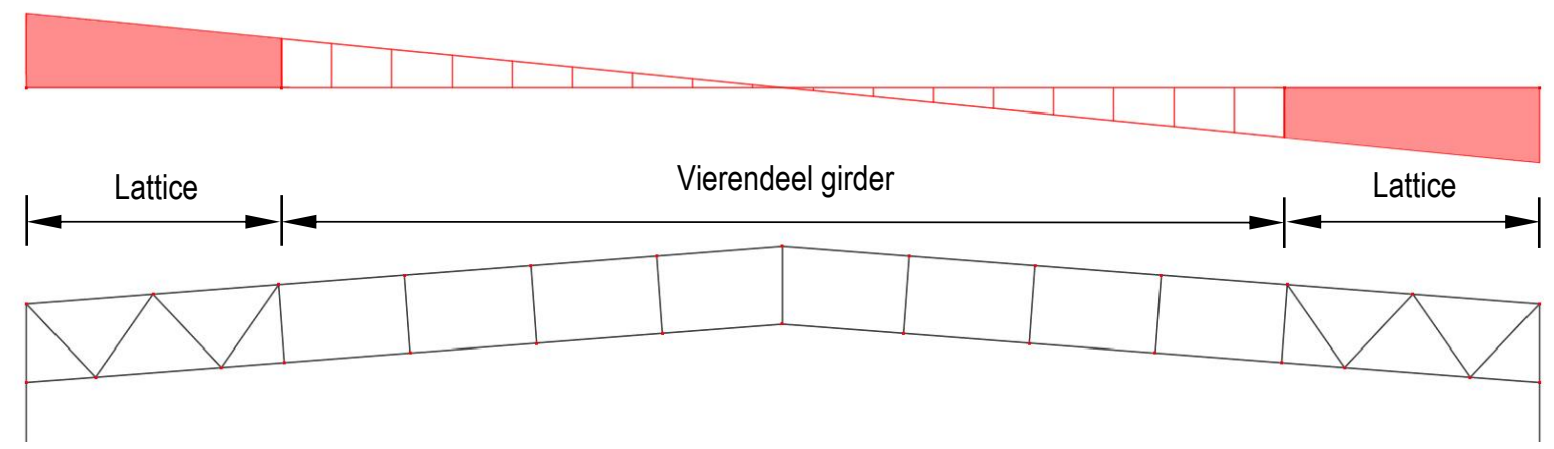

Figure 2 Shear force distribution along girder

An additional advantage of Vierendeel girders is the flexibility of the placement of the posts along the span. Their positions can be adjusted according to the load distribution to achieve a more uniform bending moment distribution along the frame girder. This is one of the main aspects of the Vierendeel girder investigated in this paper. Figure 3 shows the bending moment distributions for Vierendeel girders with constant and variable distances between posts. Moreover, the manufacture of additional posts does not significantly impact the production process, because these posts are simply extra identical elements in an already automated process.

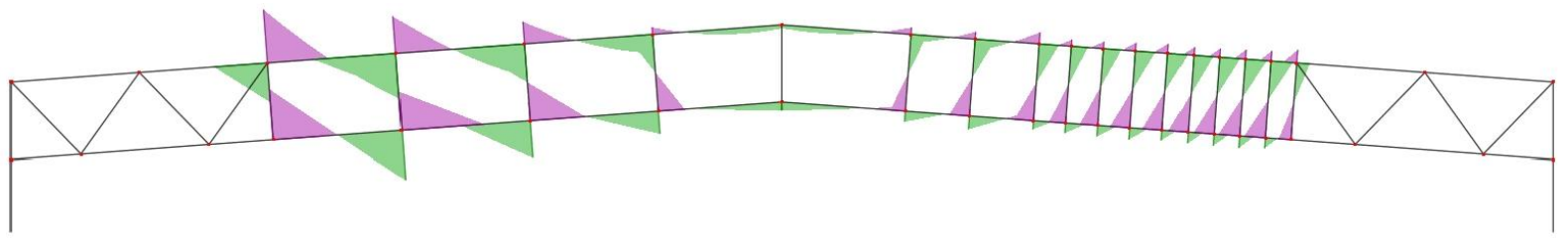

a) Constant distance between posts—nonuniform bending moment distribution

b) Variable (adjusted) distance between posts-uniform bending moment distribution

Figure 3 Bending moment distributions in Vierendeel girders with different distances between posts

\section{$3 \quad$ T-JOINT DESIGN IN VIERENDEEL GIRDERS}

It is necessary to more closely analyze the chord and post joints ( $\mathrm{T}$-joints) in Vierendeel girders before designing the frame and comparing the results because of their key role in the design of the steel frames. The cross sections obtained in T-joint design were mandatory for the chord and post selection on combined girder frames compared in this paper.

Square and rectangular hollow cross sections (SHS and RHS) were used for the chord and post members. Thus, according to EN 1993-1-8 [3], the failure mode for the T-joints considered herein is the plastic failure of the chord face or chord cross-section plastification (chord face failure, Figure 4). 


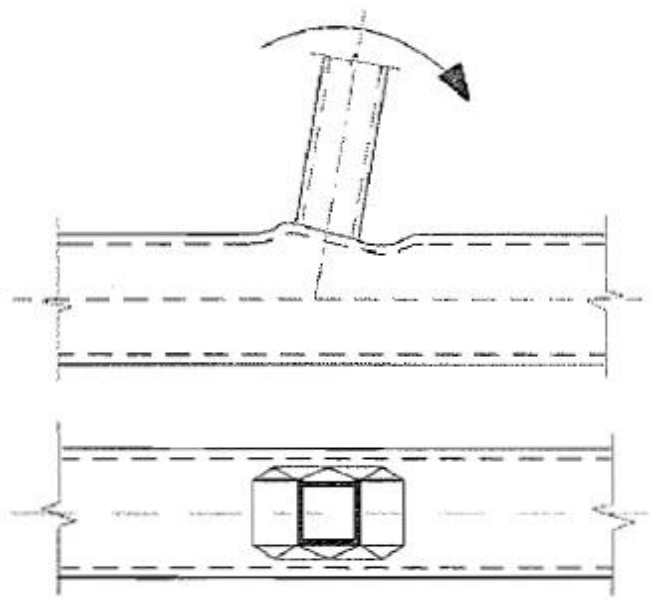

Figure 4 Chord face failure [3]

Chord face failure occurs as a result of the influence of the axial force, the bending moment, and their interaction. The design axial resistance and the design resistance moment are given in Tables 7.10 and 7.14 of EN 1993-1-8 [3], respectively, as

$\mathrm{N}_{1, \mathrm{Rd}}=\frac{\mathrm{k}_{\mathrm{n}} \cdot \mathrm{f}_{\mathrm{y} 0} \cdot \mathrm{t}_{0}{ }^{2}}{(1-\beta) \sin \theta_{1}} \cdot\left(\frac{2 \beta}{\sin \theta_{1}}+4 \sqrt{1-\beta}\right) / \gamma_{\mathrm{M} 5}$

$\mathrm{M}_{\mathrm{i}, 1, \mathrm{Rd}}=\mathrm{k}_{\mathrm{n}} \cdot \mathrm{f}_{\mathrm{y} 0} \cdot \mathrm{t}_{0}{ }^{2} \cdot \mathrm{h}_{1} \cdot\left(\frac{1}{2 \eta}+\frac{2}{\sqrt{1-\beta}}+\frac{\eta}{1-\beta}\right) / \gamma_{\mathrm{M} 5}$,

where $k_{n}$ is the parameter of the joint according to Tables 7.10 and 7.14 of EN 1993-1-8 [3], $f_{y}$ is the yield strength of the members, $h$ and $t$ are the cross-sectional geometric characteristics and are shown in Figure 5, $\gamma_{M 5}$ is the partial safety factor for joints in the hollow section lattice girder (the recommended value of 1.0 given in EN 19931-8 [3] was used), $\eta$ and $\beta$ are ratios that are explained later in this section, the subscript 0 indicates a chord parameter, and the subscript $i$ indicates a post parameter.

The influence of the axial force is negligible in the T-joints designed in this paper (approximately 1\%). Hence, the main focus is on the design moment resistance and the dependent key factors in Eq. 2. The only factors that can be influenced by changes in the geometry (selection and adjustment of chord and post cross sections) are taken into consideration. As shown in Figure 5, the considered cross-sectional dimensions are the chord wall thickness $t_{0}$, the post in-plane depth $h_{i}$, the ratio $\eta=h_{i} / b_{0}$ of the post in-plane depth to the chord out-of-plane width, and the ratio $\beta=b_{i} / b_{0} \leq 0.85$ of the post out-of-plane width to the chord out-of-plane width.

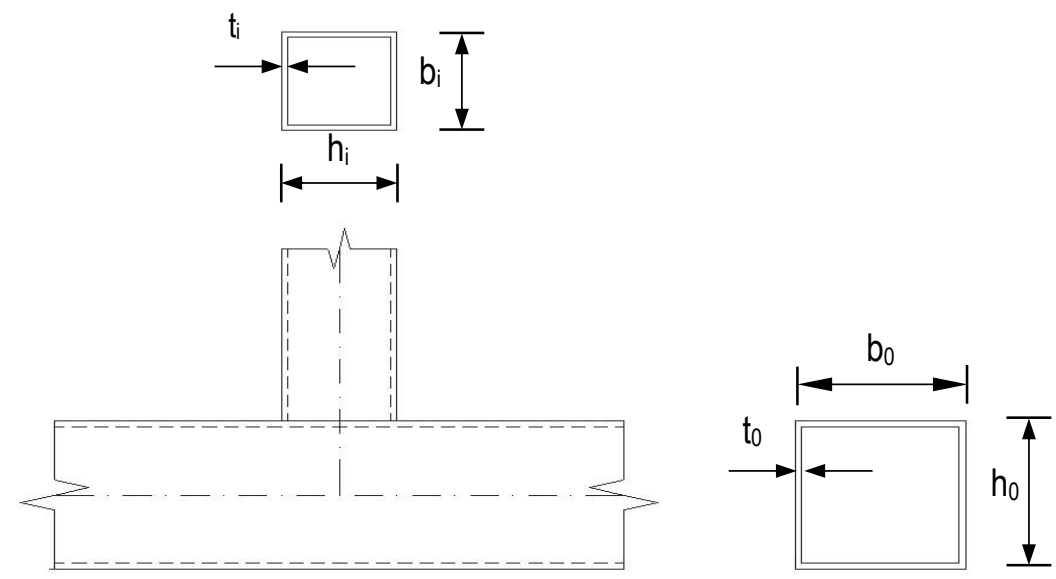

Figure $5 \mathrm{~T}$-joint and associated chord and post cross-sectional dimensions 
It is clear that increasing the chord wall thickness and post in-plane depth would significantly increase the design moment resistance, but $\beta$ is a particularly interesting factor. According to Table 7.9 of EN 1993-1-8 [3], $\beta$ is limited to 0.85 to prevent the post from encroaching on the chord corner radius. Considering all the known SHS and RHS sections on the market used in everyday engineering steel designs, the geometric compatibility of the chord and post members depending on $\beta$ may be crucial when designing T-joints.

When an appropriate post member must be determined for a given chord member, various maximum possible $\beta$ values exist. As discussed above, these values have a significant influence on the design moment resistance of the T-joints. This conclusion arose from the chord and post compatibility analysis performed in this paper, the results of which are shown in Table 1. This analysis demonstrated that $\beta$ is a key factor for increasing the design moment resistance because improvements to the other parameters (i.e., thicker chord walls, larger post in-plane depth, and higher yield strength) require greater steel consumption, construction weight, and overall price.

To conduct compatibility analysis, the chord member cross section (SHS or RHS) was first selected, as shown in the first column of Table 1, where the cross sections are grouped in rows by the out-of-plane width $b_{0}$. The chord member wall thickness $t_{0}$ is irrelevant for this matter and is not given in Table 1. It is assumed that the chord member cross-sectional dimensions and wall thickness were obtained in the member design, which precedes the connection design, but it is also worth mentioning that according to Table 7.8 of EN 1993-1-8 [3], the following conditions must be satisfied:

$\frac{\mathrm{b}_{0}}{\mathrm{t}_{0}} \leq 35$ and $\frac{\mathrm{h}_{0}}{\mathrm{t}_{0}} \leq 35$, Class 1 or 2 .

The maximum value of the out-of-plane post width $b_{i}$ (SHS or RHS) that satisfies the condition for $\beta$ can be calculated as

$\mathrm{b}_{\mathrm{i}, \max }=0.85 \cdot \mathrm{b}_{0}$.

Depending on the obtained result, the most appropriate post member cross section, i.e., that with the out-of-plane width closest to the calculated value of $b_{i, \max }$, can be determined. Finally, $\beta$ is calculated for each chord and post combination as

$\beta=\frac{\mathrm{b}_{\mathrm{i}}}{\mathrm{b}_{0}}$.

In addition, the third, fourth, and fifth columns in Table 1 give the post wall thickness and the maximum allowable steel grade that corresponds to the cross-section class conditions from Table 7.8 of EN 1993-1-8 [3]:

$\frac{b_{i}}{t_{i}} \leq 35$ and $\frac{h_{i}}{t_{i}} \leq 35$, Class 1 or 2 .

Therefore, the minimum allowable post wall thickness is

$\mathrm{t}_{\min }=\frac{\mathrm{h}_{\mathrm{i}}}{35}$.

According to this condition, the closest possible value of the post wall thickness is given in the sixth column of Table 1. According to Eq. 6, the post element must also be of Class 1 or 2; therefore, the highest steel grade that satisfies the above-mentioned condition for the closest value of post wall thickness given in column six is given in the seventh column.

The deviations of $\beta$ do not initially appear to be large, but their impact on the design moment resistance and connection design is ultimately significant. This should be considered when designing T-joints. By selecting chord and post member cross sections with a higher compatibility regarding the value of $\beta$, smaller cross sections, less steel consumption, and, most importantly, lower construction price can be achieved. 
Table 1 Chord and post member cross section compatibility for T-joints

\begin{tabular}{|c|c|c|c|c|c|c|}
\hline $\begin{array}{l}\text { Chord member } \\
b_{0} \times h_{0} \times t_{0}\end{array}$ & $\begin{array}{c}b_{i, \max }= \\
0.85 \times b_{0}\end{array}$ & $\begin{array}{l}\text { Closest post member } \\
\qquad b_{i} \times h_{i} \times t_{i}\end{array}$ & $\beta=b_{i} / b_{0}$ & $t_{i, \min }=h_{i} / 35$ & $t_{i}$ & $\begin{array}{l}\text { Post member } \\
\text { Class } 1 \text { or } 2 \text { up } \\
\text { to steel grade }\end{array}$ \\
\hline \multirow{2}{*}{ RHS $500 \times 300 \times t_{0}$} & \multirow{2}{*}{425.0} & SHS $400 \times 400 \times t_{i}$ & 0.80 & 11.43 & 12 & S355 \\
\hline & & RHS $300 \times 500 \times t_{i}$ & 0.60 & 14.29 & 16 & S420 \\
\hline \multirow{2}{*}{ RHS $450 \times 250 \times t_{0}$} & \multirow{2}{*}{382.5} & SHS $350 \times 350 \times t_{i}$ & 0.78 & 10.00 & 10 & S275 \\
\hline & & RHS $300 \times 500 \times t_{i}$ & 0.67 & 14.29 & 16 & S420 \\
\hline \multirow{2}{*}{$\begin{array}{l}\text { SHS } 400 \times 400 \times t_{0} \\
\text { RHS } 400 \times 200 \times t_{0}\end{array}$} & \multirow{2}{*}{340.0} & SHS $300 \times 300 \times t_{i}$ & \multirow{2}{*}{0.75} & 8.57 & 10 & S420 \\
\hline & & RHS $300 \times 500 \times t_{i}$ & & 14.29 & 16 & S420 \\
\hline \multirow{2}{*}{$\begin{array}{l}\text { SHS } 350 \times 350 \times t_{0} \\
\text { RHS } 350 \times 250 \times t_{0}\end{array}$} & \multirow{2}{*}{297.5} & SHS $260 \times 260 \times t_{i}$ & 0.74 & 7.43 & 8 & S355 \\
\hline & & RHS $250 \times 450 \times t_{i}$ & 0.71 & 12.86 & 16 & S460 \\
\hline \multirow{2}{*}{$\begin{array}{l}\text { SHS } 300 \times 300 \times t_{0} \\
\text { RHS } 300 \times 200 \times t_{0}\end{array}$} & \multirow{2}{*}{255.0} & SHS $250 \times 250 \times t_{i}$ & \multirow{2}{*}{0.83} & 7.14 & 8 & S420 \\
\hline & & RHS $250 \times 450 \times t_{i}$ & & 12.86 & 16 & S460 \\
\hline \multirow{2}{*}{$\begin{array}{l}\text { SHS } 260 \times 260 \times t_{0} \\
\text { RHS } 260 \times 180 \times t_{0}\end{array}$} & \multirow{2}{*}{221.0} & SHS $220 \times 220 \times t_{i}$ & 0.85 & 6.29 & 6.3 & S275 \\
\hline & & RHS $200 \times 400 \times t_{i}$ & 0.77 & 11.43 & 12 & S355 \\
\hline \multirow{2}{*}{$\begin{array}{l}\text { SHS } 250 \times 250 \times t_{0} \\
\text { RHS } 250 \times 150 \times t_{0}\end{array}$} & \multirow{2}{*}{212.5} & SHS $200 \times 200 \times t_{i}$ & \multirow{2}{*}{0.80} & 5.71 & 6 & S355 \\
\hline & & RHS $200 \times 400 \times t_{i}$ & & 11.43 & 12 & S355 \\
\hline \multirow{2}{*}{ SHS $220 \times 220 \times t_{0}$} & \multirow{2}{*}{187.0} & SHS $180 \times 180 \times t_{i}$ & \multirow{2}{*}{0.82} & 5.14 & 6 & S420 \\
\hline & & RHS $180 \times 260 \times t_{i}$ & & 7.43 & 8 & S355 \\
\hline \multirow{2}{*}{$\begin{array}{l}\text { SHS } 200 \times 200 \times t_{0} \\
\text { RHS } 200 \times 120 \times t_{0} \\
\text { RHS } 200 \times 100 \times t_{0}\end{array}$} & \multirow[b]{2}{*}{170.0} & SHS $160 \times 160 \times t_{i}$ & 0.80 & 4.57 & 5 & S355 \\
\hline & & RHS $150 \times 250 \times t_{i}$ & 0.75 & 7.14 & 8 & S420 \\
\hline \multirow{2}{*}{$\begin{array}{l}\text { SHS } 180 \times 180 \times t_{0} \\
\text { RHS } 180 \times 100 \times t_{0}\end{array}$} & \multirow{2}{*}{153.0} & SHS $150 \times 150 \times t_{i}$ & \multirow{2}{*}{0.83} & 4.29 & 5 & S420 \\
\hline & & RHS $150 \times 250 \times t_{i}$ & & 7.14 & 8 & S420 \\
\hline \multirow{2}{*}{$\begin{array}{l}\text { SHS } 160 \times 160 \times t_{0} \\
\text { RHS } 160 \times 80 \times t_{0}\end{array}$} & \multirow{2}{*}{136.0} & SHS $120 \times 120 \times t_{i}$ & \multirow{2}{*}{0.75} & 3.43 & 4 & S420 \\
\hline & & RHS $120 \times 200 \times t_{i}$ & & 5.71 & 6 & S355 \\
\hline \multirow{2}{*}{$\begin{array}{l}\text { SHS } 150 \times 150 \times t_{0} \\
\text { RHS } 150 \times 100 \times t_{0}\end{array}$} & \multirow{2}{*}{127.5} & SHS $120 \times 120 \times t_{i}$ & 080 & 3.43 & 4 & S420 \\
\hline & & RHS $120 \times 200 \times t_{i}$ & 0.80 & 5.71 & 6 & S355 \\
\hline SHS $140 \times 140 \times t_{0}$ & 1190 & SHS $100 \times 100 \times t_{i}$ & 071 & 2.86 & 3.6 & S460 \\
\hline RHS $140 \times 80 \times t_{0}$ & 119.0 & RHS $100 \times 200 \times t_{i}$ & & 5.71 & 6 & S355 \\
\hline SHS $120 \times 120 \times t_{0}$ & & SHS $100 \times 100 \times t_{i}$ & & 2.86 & 3.6 & S460 \\
\hline $\begin{array}{l}\text { RHS } 120 \times 80 \times t_{0} \\
\text { RHS } 120 \times 60 \times t_{0}\end{array}$ & 102.0 & RHS $100 \times 200 \times t_{i}$ & 0.83 & 5.71 & 6 & S355 \\
\hline SHS $100 \times 100 \times t_{0}$ & & SHS $80 \times 80 \times t_{i}$ & & 2.29 & 3 & S460 \\
\hline $\begin{array}{l}\mathrm{RHS} 100 \times 60 \times t_{0} \\
\mathrm{RHS} 100 \times 50 \times t_{0}\end{array}$ & 85.0 & $\mathrm{RHS} 80 \times 160 \times t_{i}$ & 0.80 & 4.57 & 5 & S355 \\
\hline
\end{tabular}

\section{USE OF COMBINED GIRDER IN STEEL SINGLE-STORY BUILDING}

A combined lattice and Vierendeel girder was used in a 62.0-m span industrial steel single-story building, the layout and dimensions of which are shown in Figure 6. Structural steel grade S355 was used. Multiple variant solutions were considered, as in a real construction design situation, to find the optimal solution in terms of steel consumption and labor costs. Prior to selecting the frame system, preliminary calculations were performed [6]. Actions on the structure used in the preliminary calculations [6] were the characteristic value of snow on the ground $s_{k}=0.40 \mathrm{kN} / \mathrm{m}^{2}$ and the fundamental value of the basic wind velocity $v_{b, 0}=30.0 \mathrm{~m} / \mathrm{s}$ for terrain category 0 , according to Table 4.1 of EN 1991-1-4, [7]. Calculations and steel frame design were performed in accordance with EN 1993-1-1 [8]. 


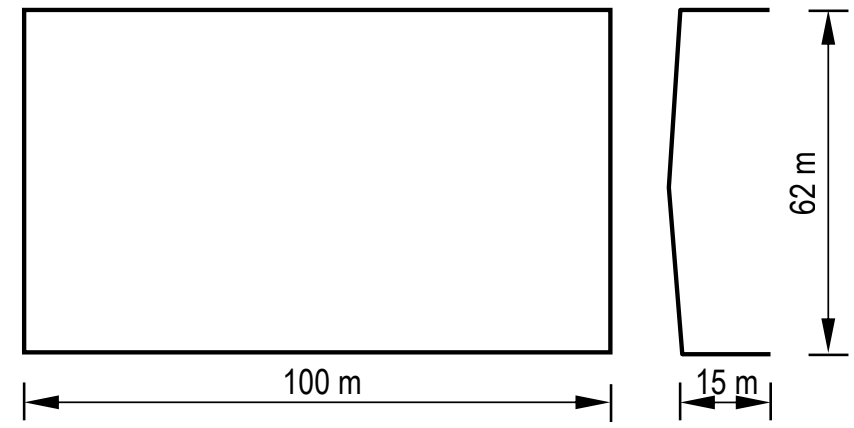

Figure 6 Layout of single-story building and frame dimensions

To select the optimal static system, i.e., the post placement in the Vierendeel girder, the shape of the frame and all the constants and variables must be defined for the comparison. As mentioned earlier, the frame span is $62.0 \mathrm{~m}$ with a column height of $15.0 \mathrm{~m}$ and a ridge height of $17.3 \mathrm{~m}$. The girder truss height is $3.1 \mathrm{~m}$ and was obtained using $h=L / 20$, as recommended by Androić et al. [9].

In addition, two cases with frame spacings 12.5 and $5.0 \mathrm{~m}$ were analyzed. The case with the $12.5-\mathrm{m}$ spacing included purlins in longitudinal direction, whereas the case with the 5.0-m spacing did not; thus, the load in the case of the 12.5-m spacing was higher. The higher load from the secondary girders and the higher self-weight of the frame system resulted in high bending moments in Vierendeel posts and consequently required a very high weld thickness in the Vierendeel T-joints; therefore, the 5.0-m frame spacing was introduced.

The positions of the nodes in the truss girder were adjusted according to the calculated girder truss height. The frame girder was divided into 12 fields, with six on each side of the double pitched frame roof. Thus, the obtained node distance remained constant because of the presumed purlins and horizontal stabilization system that connect within those nodes (Figure 7). As stated in Section 2, a truss girder was used at the edges of the frame girder and spans two fields. A Vierendeel girder was used in the remaining fields with posts perpendicularly positioned between chords. The posts in the Vierendeel girder shown in Figure 7 (default post elements) remained constant during this process to satisfy the abovementioned purlin and stabilization system locations.

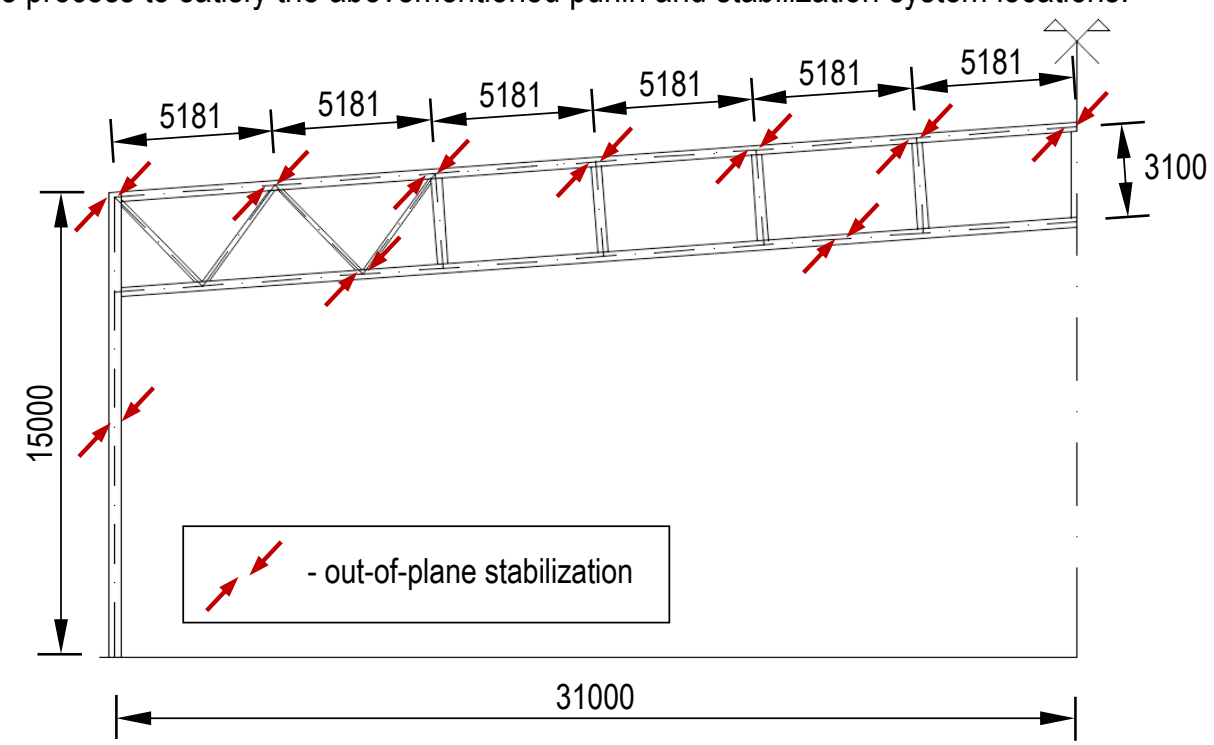

Figure 7 One-half of the combined girder frame

In this investigation, the number of additional posts in each Vierendeel girder field was varied. Logically, the number of posts per field should decrease toward the center of the frame span because of the reduction in the shear force. Because of the symmetry around the central vertical axis, four characteristic fields of the Vierendeel girder in one-half of the frame can be considered to represent the entire Vierendeel girder. Additional posts were added to these fields where required. The fields were labeled Fields 1-4 (F1-F4), and the frame types are hereafter referred to, based on the number of additional posts in each of these fields, as "type A1-A2-A3-A4," where A1-A4 
represent the numbers of additional posts in Fields $1-4$. For example, the frame in Figure $8 \mathrm{a}$, called combined frame type $0-0-0-0$, contains only the default posts and no additional posts. (The same frame type is shown in Figure 9.) Another example is combined frame type 3-2-1-0 (Figure 8b), which contains three additional posts in the first field, two in the second, one in the third, and none in the fourth.

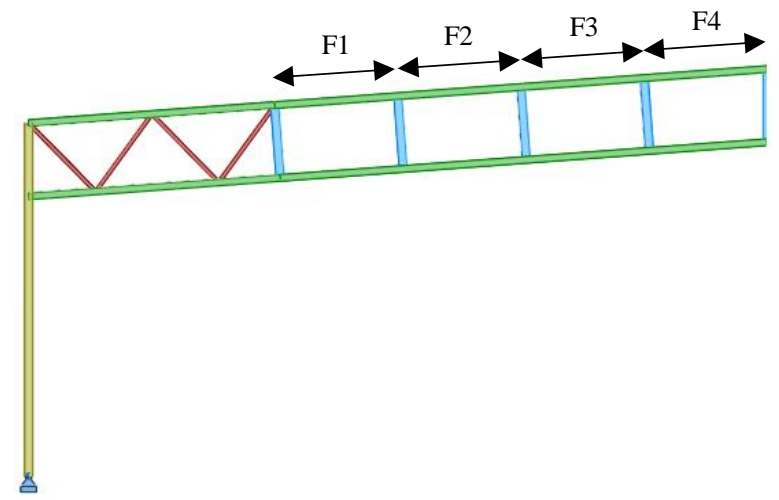

a) Combined frame type 0-0-0-0

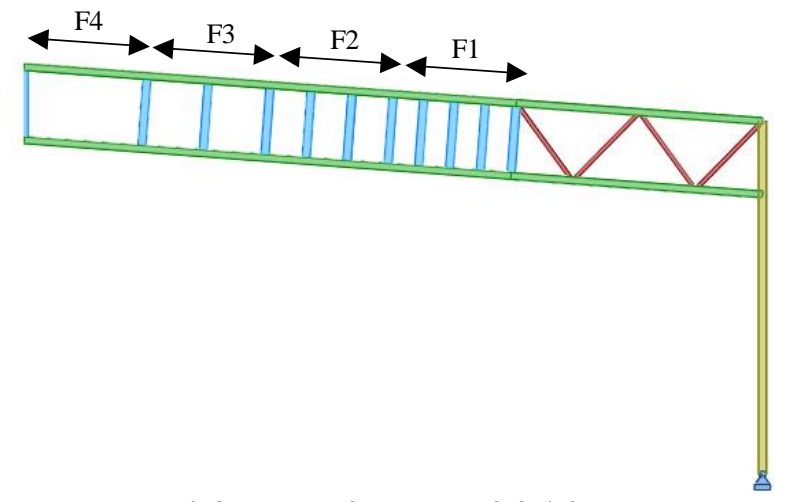

b) Combined frame type 3-2-1-0

Figure 8 Characteristic fields in combined girder frames and examples of frame types

It is important to note that the margin lattice girder elements were modeled as truss elements (pinned-pinned end releases) that experienced only axial forces, whereas all other elements experienced all internal forces and bending moments.

Because the main objective of this study was to determine the optimal number and positioning of the Vierendeel posts, the following calculations were made on frame systems with constant cross sections for all analyzed combined frame types with frame spacings of 12.5 and $5.0 \mathrm{~m}$ (Figures $9 \mathrm{a}$ and $\mathrm{b}$, respectively). These cross sections were adopted from a previous study [6] and designed for only combined frame types 3-2-1-0 and 43-1-0.

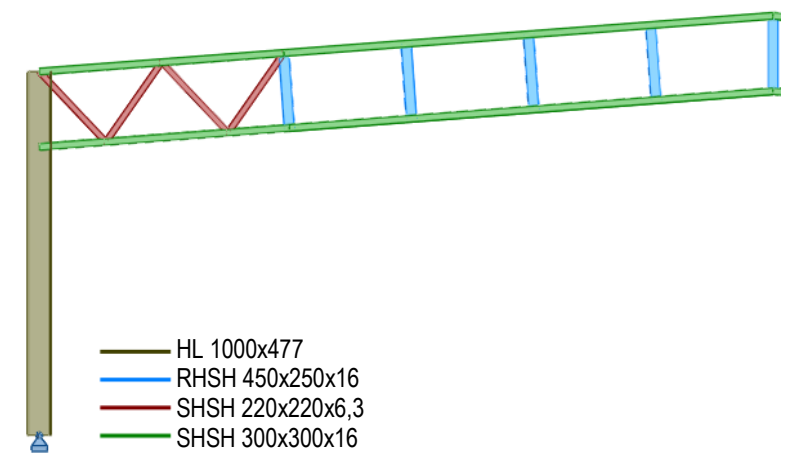

a) 12.5-m frame spacing

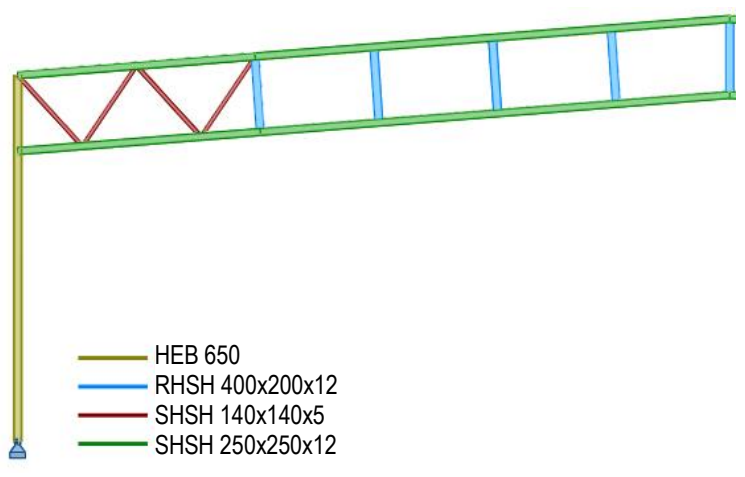

b) 5.0-m frame spacing

\section{Figure 9 Finite element models of frame and associated cross sections}

The output data of the calculations are the extreme positive and negative values of the bending moments on the upper and lower sides of the Vierendeel girder post (vertical post). The locations of the extreme bending moments were obtained (either in one of four characteristic fields or at the default boundary posts between the fields), and their behavior based on the number of additional posts was observed. It is important to record the extreme bending moments on the vertical posts because they are used as reference values for T-joint design. The extreme bending moments on the upper and lower sides of the element are designated $M_{1}$ and $M_{2}$, respectively. For example, in Figure $10, M_{1}=171 \mathrm{kNm}$, and $M_{2}=-167 \mathrm{kNm}$. 


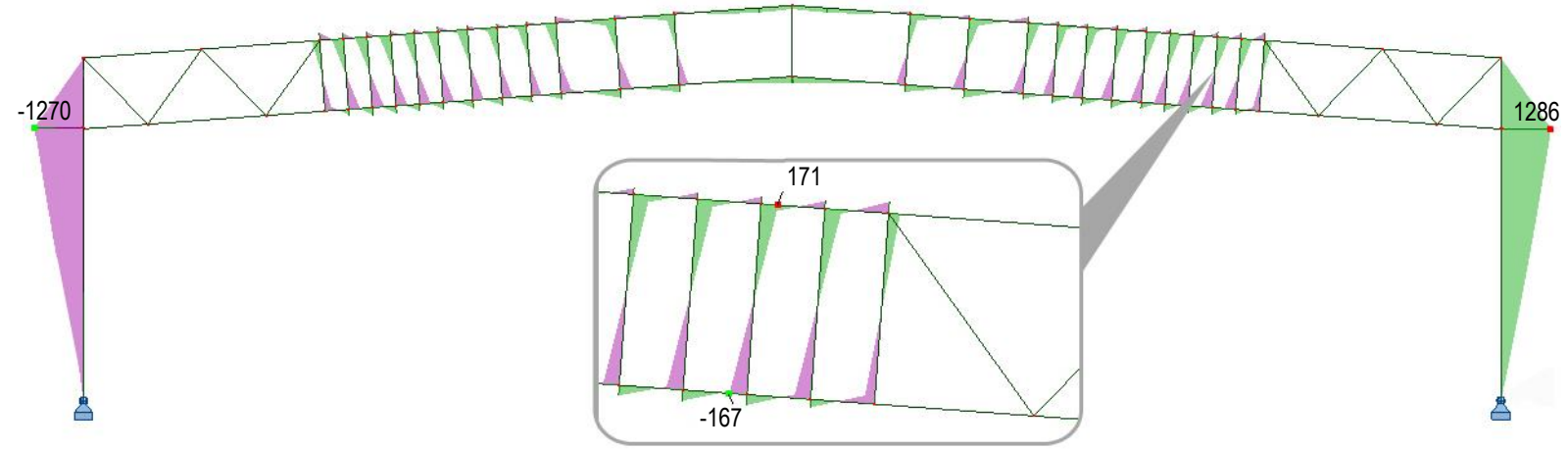

Figure 10 Diagram of bending moments for combined frame type 4-3-1-0 with associated extreme values

The calculation began with combined frame type $0-0-0-0$, and new posts were added to each subsequent calculation based on the location of the extreme bending moment in the previous case. New post elements were added to the field with the bending moment of the greatest magnitude to achieve a more uniform bending moment distribution. These locations are highlighted in the final columns of Tables 2 and 3 . As an example, for the second frame type in Table 2 (type 1-0-0-0), the extreme bending moment is located on the boundary element between the first and the second fields; thus, the two cells are shaded. Further, for the eighth case in Table 2 (type 4-2-1-0), the extreme is in F2. To achieve a more uniform bending moment distribution, a new post was added in that field, yielding the next case, type 4-3-1-0, and "moving" the extreme bending moment to F1. New posts are added to the fields with shaded cells, which is logical because a denser placement of post elements creates a more uniform bending moment distribution.

Table 2 Results of optimal static system selection for 12.5-m frame spacing

\begin{tabular}{ccccccccc}
\hline $\begin{array}{c}\text { Additional posts } \\
\text { (Combined frame type) }\end{array}$ & $\begin{array}{c}\boldsymbol{M}_{1, \max } \\
{[\mathrm{kNm}]}\end{array}$ & $\begin{array}{c}\boldsymbol{M}_{1, \min } \\
{[\mathrm{kNm}]}\end{array}$ & $\begin{array}{c}\boldsymbol{M}_{2, \max } \\
{[\mathrm{kNm}]}\end{array}$ & $\begin{array}{c}\boldsymbol{M}_{2, \min } \\
{[\mathrm{kNm}]}\end{array}$ & \multicolumn{3}{c}{$\begin{array}{c}\boldsymbol{M}_{1, \max } \text { and } \boldsymbol{M}_{2, \min } \\
\text { location }\end{array}$} \\
\hline 0-0-0-0 & 1469 & -718 & 717 & -1468 & F1 & F2 & F3 & F4 \\
$1-0-0-0$ & 1050 & -511 & 510 & -1050 & F1 & F2 & F3 & F4 \\
$1-1-0-0$ & 864 & -414 & 411 & -860 & F1 & F2 & F3 & F4 \\
$2-1-0-0$ & 659 & -302 & 301 & -657 & F1 & F2 & F3 & F4 \\
$2-1-1-0$ & 626 & -286 & 285 & -626 & F1 & F2 & F3 & F4 \\
$2-2-1-0$ & 600 & -276 & 275 & -599 & F1 & F2 & F3 & F4 \\
$3-2-1-0$ & 460 & -205 & 206 & -461 & F1 & F2 & F3 & F4 \\
$4-2-1-0$ & 427 & -187 & 188 & -429 & F1 & F2 & F3 & F4 \\
$4-3-1-0$ & 375 & -158 & 159 & -376 & F1 & F2 & F3 & F4 \\
\hline
\end{tabular}

Table 3 Results of optimal static system selection for $5.0-\mathrm{m}$ frame spacing

\begin{tabular}{ccccccccc}
\hline $\begin{array}{c}\text { Additional posts } \\
\text { (Combined frame type) }\end{array}$ & $\begin{array}{c}\boldsymbol{M}_{1, \max } \\
{[\mathrm{kNm}]}\end{array}$ & $\begin{array}{c}\boldsymbol{M}_{1, \min } \\
{[\mathrm{kNm}]}\end{array}$ & $\begin{array}{c}\boldsymbol{M}_{\mathbf{2}, \max } \\
{[\mathrm{kNm}]}\end{array}$ & $\begin{array}{c}\boldsymbol{M}_{2, \min } \\
{[\mathrm{kNm}]}\end{array}$ & \multicolumn{3}{c}{$\begin{array}{c}\boldsymbol{M}_{1, \max } \text { and } \boldsymbol{M}_{2, \min } \\
\text { location }\end{array}$} \\
\hline 0-0-0-0 & 631 & -345 & 347 & -634 & F1 & F2 & F3 & F4 \\
$1-0-0-0$ & 457 & -250 & 241 & -447 & F1 & F2 & F3 & F4 \\
$1-1-0-0$ & 374 & -198 & 198 & -371 & F1 & F2 & F3 & F4 \\
$2-1-0-0$ & 293 & -150 & 141 & -283 & F1 & F2 & F3 & F4 \\
$2-1-1-0$ & 273 & -136 & 136 & -274 & F1 & F2 & F3 & F4 \\
$2-2-1-0$ & 269 & -131 & 130 & -267 & F1 & F2 & F3 & F4 \\
$3-2-1-0$ & 207 & -98 & 97 & -204 & F1 & F2 & F3 & F4 \\
$4-2-1-0$ & 196 & -95 & 95 & -196 & F1 & F2 & F3 & FP4 \\
$4-3-1-0$ & 171 & -76 & 75 & -167 & F1 & F2 & F3 & F4 \\
\hline
\end{tabular}


Nine calculations were performed for each frame spacing case for nine combined frame types with different numbers of additional posts. As expected, the extreme bending moment decreased as the number of posts increased in both cases, and their locations were identical because the static systems were the same (Figure 11).

$\square \mathrm{M} 1$, $\max \quad \square \mathrm{M} 2$, min

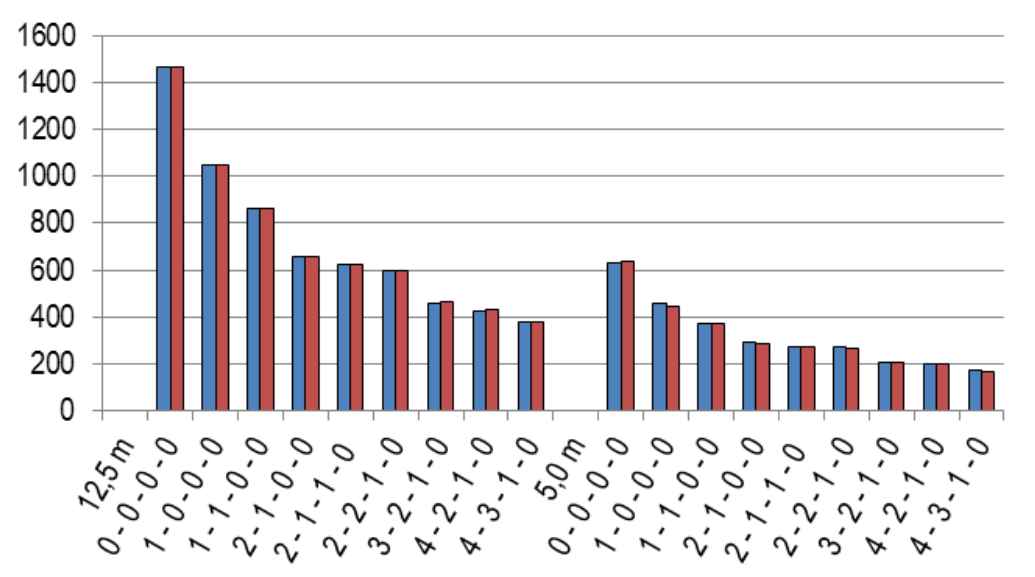

Figure 11 Reduction of extreme bending moments by adding vertical posts

\section{COMPARISON RESULTS AND CONCLUSION}

In this section, the following two frame systems were selected for an in-depth comparison: type 4-3-1-0, which yields the lowest bending moment, and type 3-2-1-0, which yields a slightly higher bending moment than type 4-31-0 with fewer additional posts.

The two selected combined frames were compared with a conventional lattice girder frame in terms of their steel consumption. Considering the two frame spacing cases for each frame type yields a total of six frames. The weld thicknesses in the Vierendeel girder T-joints were also compared.

Figure 12 shows that the lattice girder frames are advantageous in terms of weight, i.e., less steel is required. Among the combined girder frames, which in both cases of the same frame spacing had the same cross sections, the difference in the weight resulting from the additional posts in frame type 4-3-1-0 was minimal.

- Construction weight (t)

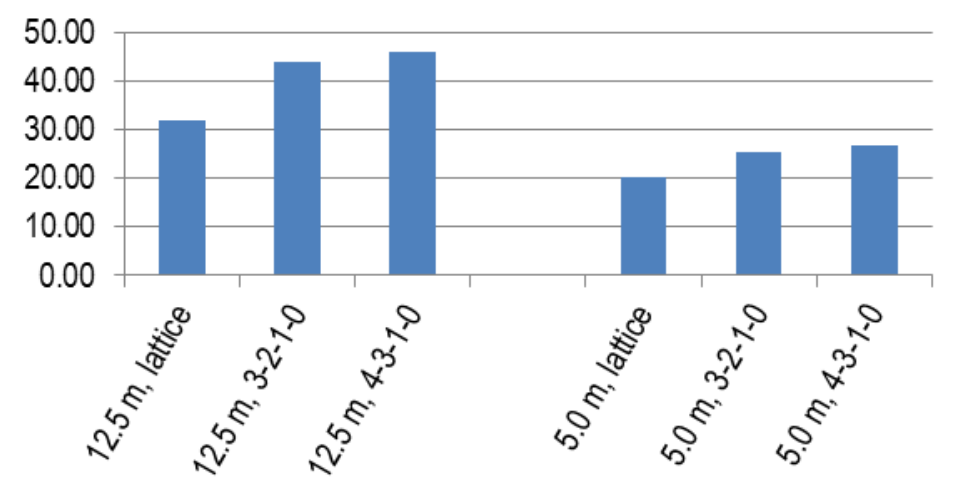

Figure 12 Frame weight comparison

The key difference between the two compared combined girder frame types (types 3-2-1-0 and 4-3-1-0) is the weld thickness required in the T-joint connection design. Weld thickness plays an important role in determining the labor cost because thicker welds require a greater amount of labor, which ultimately increases the construction cost. As the number of additional elements in the Vierendeel girder increases, the weld thickness decreases (Figure 13). This is a result of the smaller bending moment requirement in the T-joint design, as previously explained. 


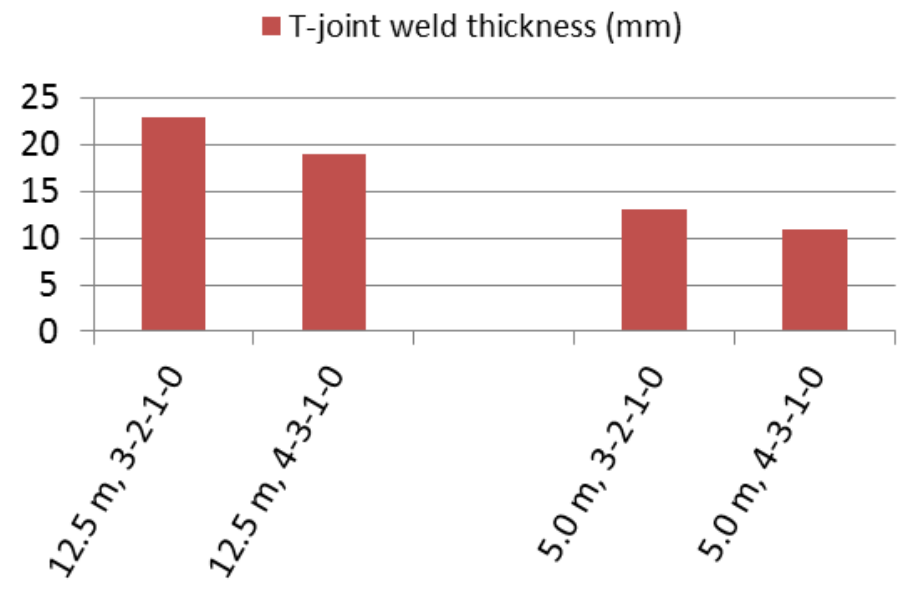

Figure $13 \mathrm{~T}$-joint weld thickness comparison

It should be noted that according to Packer et al. [10], the minimum weld thickness in the hollow section Tjoint should be

$a \geq 1.10 t$ for $S 355\left(f_{y i}=355 \mathrm{~N} / \mathrm{mm}^{2}\right)$.

In the case of the 12.5-m frame spacing, this justifies the use of the additional posts for type 4-3-1-0 at the cost of increased construction weight because the required weld thickness is higher than the minimum thickness given by Eq. 8. In contrast, for type 4-3-1-0 with a 5.0-m frame spacing, the weld thickness must be smaller than the minimum thickness given by Eq. 8; thus, in this case, type 3-2-1-0 is a better solution.

Noting that the weights of frames with different spacings cannot be directly compared, because the weights of other structural elements (e.g., secondary girders, secondary columns, bracings) are not considered in this study, the following advantages and disadvantages of each system can be highlighted.

The lattice girder frame is a better solution if the aim is to reduce steel consumption. The combined girder requires far more skill and far more analysis time than the lattice girder. However, regarding the frame mass and automated production, the combined lattice and Vierendeel girder has the advantage of simple design because of the low precision requirements during production, good connection accessibility during the welding process, vertical element cuts, and use of automated production for elements of equal length. In this case, analysis of the optimal additional post element arrangement is advised along with preliminary selection of chord and post cross sections depending on their geometrical compatibility.

\section{References}

[1] Autodesk Robot Structural Analysis Professional 2015, http://www.autodesk.com, (Accessed 24.09.2015.)

[2] Kurrer, K.E. 2008: The history of the theory of structures, Ernst \& Sohn, Berlin

[3] EN 1993-1-8: 2005+AC:2009: Eurocode 3: Design of steel structures - Part 1-8: Design of joints, Brussels, Belgium: European Committee for Standardization

[4] Kindmann, R.; Kraus, M.; Josat, O. 2009: Construction of a seven bay steel building with hollow cross-section lattice girders, Nordic Steel Construction Conference 2009

[5] Josat, O. 2010: PREON - The flexible standard in hall construction, Tubular Structures XIII, Proceedings of the 13th International Symposium on Tubular Structures, Hong Kong, China, 15-17 December 2010

[6] Ptiček, M. 2015: Design of steel industrial building with a roof span of $62 \mathrm{~m}$, Graduate work, Faculty of Civil Engineering, University of Zagreb, Zagreb, mentor: Dujmović, D., co-mentor: Lukačević, I.

[7] EN 1991-1-4: 2005+AC:2010+A1:2010: Eurocode 1: Actions on structures - Part 1-4: General actions - Wind actions, Brussels, Belgium: European Committee for Standardization

[8] EN 1993-1-1: 2005+AC:2009: Eurocode 3: Design of steel structures - Part 1-1: General rules, Brussels, Belgium: European Committee for Standardization

[9] Androić, B.; Dujmović, D.; Džeba, I. 2008: Čelične konstrukcije 1, IA Projektiranje, Zagreb

[10] Packer, J.A.; Wardenier, J.; Zhao, X.-L.; van der Vegte, G.J.; Kurobane, Y. 2009: Design guide for rectangular hollow section (RHS) joints under predominantly static loading, Second Edition, CIDECT 